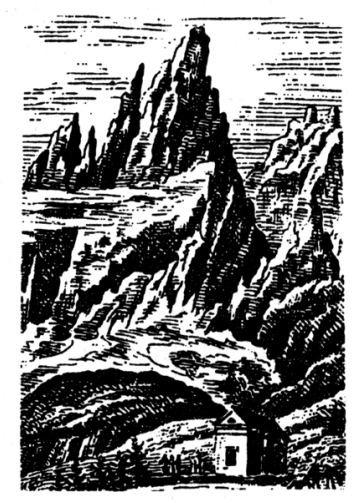

Katarzyna Tałuć

Uniwersytet Śląski

tkat1970@02.pl

DOI: $10.19195 / 2084-4107.11 .18$

\title{
Zdobywanie, wędrowanie, obcowanie. Problematyka przekraczania granic w eksploracji gór na łamach prasy dwudziestolecia międzywojennego
}

Słowa-klucze: Góry, turystyka, prasa, dydaktyka

Keywords: mountains, tourism, press, didactics

Conquering, hiking, communing. The inter-war press on crossing boundaries in the exploration of mountains

\section{Summary}

The aim of the article is to present views, published in selected periodicals of the inter-war period, on the exploration of the mountains and, above all, the experiences associated with it. The author uses as her examples articles published in specialist periodicals like Pamiętnik Towarzystwa Tatrzańskiego, Przeglad Turystyczny, Taternik, Wierchy — published by the Polish Tatra Society - and in periodicals dedicated to broadly defined tourism and sightseeing, i.e. Turysta $w$ Polsce - 
periodical of the Polish Tatra Society, Polish Skiing Society and Polish Kayaking Society; Ziemia - monthly of the Polish Sightseeing Society. She points to the polemic concerning classical Alpine mountaineering and competitive mountaineering as well as elements of transgression present in both kinds of high mountain exploration. She also discusses how the model of mass mountain tourism emerging in the inter-war period was described.

Dwudziestolecie międzywojenne w historii taternictwa to czas intensywnej eksploracji nie tylko Tatr, lecz także innych pasm górskich, w tym tych najwyższych lub w rankingu wspinaczy uznawanych za najtrudniejsze do zdobycia. Organizowanym wyprawom wysokogórskim, sukcesom polskich, i nie tylko, wspinaczy towarzyszyły dyskusje na temat istoty, sensu podejmowania trudu penetracji przestrzeni górskiej. Ich śladem są artykuły publikowane na łamach czasopism specjalistycznych, jak np. „Pamiętnik Towarzystwa Tatrzańskiego”, „Przegląd Turystyczny”, „Taternik”, „Wierchy” — wydawnictw Polskiego Towarzystwa Tatrzańskiego — oraz w periodykach poświęconych szeroko rozumianej problematyce turystyczno-krajoznawczej, czyli w „Turyście w Polsce” — organie Polskiego Towarzystwa Tatrzańskiego, Polskiego Związku Narciarskiego i Polskiego Towarzystwa Kajakowego oraz „Ziemi” — miesięczniku Polskiego Towarzystwa Krajoznawczego.

Wybór zakresu chronologicznego analizowanego materiału prasowego zasygnalizowany w tytule został zatem podyktowany, po pierwsze, istnieniem wyraźnie odznaczającego się po pierwszej wojnie światowej etapu w rozwoju taternictwa, w tym krystalizacji polskiego alpinizmu mającego odzwierciedlenie między innymi w sukcesach ekip wspinaczkowych w Alpach, Kaukazie, górach Ameryki Południowej czy na Spitsbergenie. Po drugie, ponowne zaistnienie na mapach Europy po przeszło stu latach niebytu państwa polskiego oznaczało odmienną sytuację polityczną, społeczną, prawną, ekonomiczną mającą wpływ na funkcjonowanie towarzystw, organizacji i związanych z nimi mediów, głównie prasy. W latach 1918-1939 podjęto również prace nad stworzeniem zrębów państwowej polityki turystycznej, wyznaczając zadania, jakie przewidziano do realizacji przy wsparciu finansowym organów władzy, i przede wszystkim kreując określony model turystyki uwzględniający pierwiastek ideologiczno-wychowawczy. Niniejszy artykuł nie stanowi, z oczywistych względów, opracowania wyczerpującego opis zjawisk i problemów podejmowanych przez autorów tekstów prasowych poświęconych zagadnieniom eksploracji gór. Problematyka ta bowiem ze względu chociażby na różnorodne konteksty, które należałoby uwzględnić w analizie i interpretacji wypowiedzi — np. politycznych, psychologicznych, estetycznych, lingwistycznych - winna być przedmiotem szerszego opracowania. Postanowiono jedynie zasygnalizować wyróżniające się w wybranych czasopismach poglądy na temat zdobywania, poznawania przestrzeni górskiej i przede wszystkim przeżyć towarzyszących owej eksploracji.

$\mathrm{Na}$ łamach specjalistycznych czasopism polskich dyskusje nad transgresyjnością eksploracji gór - w sensie scjentystycznym, a także psychologicznym — były obecne od początku wydawania periodyków. Stefan Komornicki w „Ta- 
terniku” z 1909 r. ${ }^{1}$, natomiast Mieczysław Świerz w „Pamiętniku Towarzystwa Tatrzańskiego" z 1913 r. $^{2}$, pisząc o historii polskiego taternictwa, zastanawiali się między innymi nad odpowiedzią na pytanie o pobudki do chodzenia po górach. Próbowali dokonywać pierwszych klasyfikacji osób wędrujących w góry, biorąc pod uwagę motywy, jakimi się one kierowały. Tym samym autorzy wskazywali na doznania, przeżycia czy konieczność zaspokajania konkretnych potrzeb poprzez takie formy spędzania wolnego czasu. Zygmunt Aleksander Klemensiewicz, jeden z najaktywniejszych polskich taterników, pionier turystyki zimowej, często wypowiadał się na temat potrzeby sprawdzania się w konkretnych warunkach górskich, potrzebie zwycięstwa, walki towarzyszącej żądzy przygód i naturalnej życiowej skłonności człowieka do podejmowania czynów sprawdzających jego wytrzymałość fizyczną i psychiczną ${ }^{3}$. Komornickiego, Klemensiewicza, Świerza czy Lewickiego ${ }^{4}$, wypowiadających się o motywacji osób uprawiających taternictwo, inspirowały również dokonania europejskich alpinistów przełomu XIX $\mathrm{i} \mathrm{XX} \mathrm{w}^{5}$.

Od połowy XIX w. ekipy Anglików, wspomagane miejscowymi przewodnikami, zaczęły zdobywać kolejne najwyższe szczyty Alp, przy czym starano się wybierać te, na których nikt jeszcze nie stanął i których osiągnięcie mogło być uznane za szczególnie efektowne. W tym czasie, okrzykniętym „złotą epoką” alpinizmu europejskiego (angielskiego), pojawiły się założenia ideologii alpinizmu, na przykład: należy wchodzić tam, gdzie jeszcze żaden inny człowiek nie wszedł; istotny jest stopień trudności do pokonania. Za największe osiągnięcie tej epoki należy uznać zdobycie w 1865 r. pod wodzą Edwarda Whympera Matterhornu, uznawanego dotąd za niedostępny. Po zdobyciu większości szczytów alpejskich, zwłaszcza odznaczających się dużym stopniem trudności przy wchodzeniu, zwrócono uwagę na góry innych kontynentów. Anglicy wyruszyli w Kaukaz, Niemcy do Afryki. Kurczenie się górskiego dziewiczego świata niejako automatycznie narzuciło określanie innych celów, motywacji towarzyszących wspinaczom wysokogórskim. Na dalszy plan zeszła odpowiedź na pytanie „co zdobyć?”. Priorytetem stało się ,,jak to zrobić?”. Schyłek XIX w. w dziejach alpinizmu charakteryzował się akcentowaniem wyczynów dokonywanych w duchu sportowym. Efektem integralnym alpinizmu sportowego były także dyskusje, spory na temat tzw. korzystania z ułatwień, a więc sprzętu, który pozwalał na pokonywanie dróg niedostępnych dla wspinaczki klasycznej. Nawet ówcześni mistrzowie zdobywania szczytów tylko dzięki sprawności własnego ciała, jak Hans Dülfer, sięgnęli po pomoc i w miejscach szczególnie trudnych stosowali haki, pętle linowe, wahadła.

1 Zob. S. Komornicki, Z dziejów taternictwa polskiego (Szkic), „Taternik” 1909, nr 4, s. 69-77.

2 Zob. M. Świerz, Zarys dziejów taternictwa polskiego, „Pamiętnik Towarzystwa Tatrzańskiego" 34, 1913, s. 49-69.

3 Zob. Z.A. Klemensiewicz, Zasady taternictwa, Lwów 1913.

4 Zob. artykuł A. Lewickiego pt. Alpinizm i taternictwo drukowany w „Gazecie Lwowskiej” z 1906 r. w numerach 181, 182, 184, 186, 188.

5 Por. E. Roszkowska, Taternictwo polskie. Geneza i rozwój do 1914 roku, Kraków 2013. 
Technika ta, zwana hakową, szybko zyskała popularność, otwierając na początku $\mathrm{XX}$ w. nową erę alpinizmu. Początek tego stulecia w historii alpinizmu zaznaczył się między innymi obecnością sporów między zwolennikami wspinaczki klasycznej, której patronował duch poznawczo-odkrywczy, a alpinizmem sportowym, nastawionym na wyniki, wiążącym się z przekraczaniem, przesuwaniem granic fizycznych możliwości człowieka oraz jego wytrzymałości psychicznej ${ }^{6}$.

Po zakończeniu pierwszej wojny światowej dyskusje na temat sportowych aspektów ideologii alpinizmu w specjalistycznych czasopismach, w tym polskich, zintensyfikowały się. Marian Sokołowski w obszernym artykule pod tytułem $O$ istocie i drogach rozwoju nowoczesnego taternictwa, opublikowanym na łamach „Taternika” za lata 1923-19247, zdefiniował taternictwo jako sport, ponieważ: ,jego uprawianie było formą spędzania czasu wolnego, co miało znamiona ludyzmu; służyło sprawdzeniu możliwości fizycznych osób go uprawiających; było udziałem większej grupy ludzi"8. W dalszej części tekstu, rozbudowując ową definicję, Sokołowski podkreślał jednak, że taternictwo wśród innych dyscyplin sportowych miało odrębne miejsce. Jego wyjątkowość zasadzała się bowiem między innymi na bogatym katalogu emocji doświadczanych przez osoby eksplorujące góry. Rywalizacja popychająca wspinaczy do podejmowania coraz trudniejszych wyzwań zawsze winna, zdaniem publicysty, mieć podstawy głęboko etyczne i służyć przede wszystkim doskonaleniu techniki i umiejętności wspinaczkowych, a nie ustanawianiu rekordów. Chodzenie po górach, obcowanie z nieskażoną przyrodą, pokonywanie własnych słabości to źródło radości, upojenia. Sokołowski eksplorację gór rozumiał nie tylko jako sport, lecz także jako naukę, wiedzę i sztukę, a szczególne znaczenie w tak szeroko postrzeganym taternictwie przypisywał powinowactwu z ostatnią z wymienionych sfer działalności człowieka:

A w taternictwie pierwiastek twórczości czyż nie stoi na pierwszym miejscu? Czyż taternik nie jest twórcą w pełnym tego słowa znaczeniu przez swe czyny? I nie to, że twory te nie mają bytu realnego w piśmie, marmurze lub na płótnie. Byt ich jest nieskończenie trwalszy, bo w skarbnicy ducha złożony9 .

W wizji taternictwa Sokołowskiego, wypływającej z romantycznych koncepcji estetycznych, taternik został porównany do rycerza, który dysponując bronią w postaci czekana i liny, wyrusza na wyprawę w nieznane krainy (góry — Tatry), aby żyć „barwnym i bogatym życiem”10. Podejmowanie trudu zdoby-

${ }^{6}$ Zob. E. Roszkowska, Alpinizm europejski 1919-1939. Ludzie - tendencje - osiagnięcia, Kraków 2007, s. 26-45.

7 M. Sokołowski, O istocie i drogach rozwoju nowoczesnego taternictwa, „Taternik” 10, 1923-1924, s. 11-25.

8 Ibidem, s. 12.

9 Ibidem, s. 14.

10 Ibidem, s. 15. 
wania kolejnych szczytów, pasm, wysiłku tak odmiennego od krzątaniny wokół prozaicznych, codziennych spraw pozwalało odczuć,

jak w mięśniach naszych zbierają się ogromne zapasy energii, wystarczającej do tytanicznych zda się wysiłków, jak rosną w nas moce ducha, jak zaostrza się rozum, krzepnie w stal wola, rozpala prometejskie ognisko uczuć szczytnych, wszechogarniających. Czujemy się do czynów wielkich ${ }^{11}$.

We wstępie rozważań o taternictwie Sokołowski wskazał pobudki, jakimi kierował się, podejmując ten temat. Publicysta jako jeden z inicjatorów założenia Sekcji Tatrzańskiej Akademickiego Związku Sportowego w Krakowie, obserwując wzmożenie aktywności młodych wspinaczy i coraz częstsze dyskusje dotyczące wyczerpywania się tak zwanych ,problemów tatrzańskich”, a więc braku nowych, oryginalnych wyzwań, poczuwał się do wytyczenia nowych przedsięwzięć w eksploracji polskich gór.

Nie mniejsze znaczenie w kształtowaniu obrazu publicystyki poruszającej zagadnienia nowoczesnego alpinizmu miały doniesienia o sukcesach lub porażkach wypraw wysokogórskich. W informacje na temat przebiegu kolejnych angielskich ekspedycji na najwyższą górę świata, Mount Everest, wsłuchiwała się cała społeczność wspinaczy, a śmierć, podczas trzeciej wyprawy — w 1924 r., George'a Mallory'ego oraz Andrew Irvine'a przyjęto z nieukrywanym żalem. Bronisław Romaniszyn na łamach „Wierchów” w 1925 r. opublikował obszerny artykuł pt. Ideologia apinistyczna Mallory'ego (Wyprawy na Mount Everest) ${ }^{12}$ będący hołdem dla tragicznie zmarłego angielskiego alpinisty. Opisy trzech ekspedycji — z 1921, 1922 i 1924 r. — stały się tłem dla charakterystyki osobowościowej Mallory’ego i zaprezentowania poglądów alpinisty, uznawanego za jednego z najwybitniejszych w dwudziestoleciu międzywojennym, na temat celu i sensu penetracji najwyższych partii gór. W 1921 r., jak podkreślał Romaniszyn, zadaniem przybyłych w Himalaje alpinistów było przede wszystkim zapoznanie się z topografią i orografią terenu. Mallory szukał dróg dojścia do szczytu a następnie możliwości wejścia na niego. Aby oddać wrażenia, jakich doznawał alpinista u stóp „Matki-Góry”, Romaniszyn cytował fragmenty sprawozdań Anglika, wybierając jednak te świadczące o odczuwaniu pokory i podziwu dla majestatu przyrody. Przywoływano opisy doświadczeń emocjonalnych, uczucia respektu wobec wielkości, majestatu, grozy, harmonii budowy „Dachu Świata”. Według Romaniszyna owe żmudne przygotowania, w efekcie przynoszące poznanie środowiska, w tym przyrody, ludzi zamieszkujących egzotyczny dla Europejczyka Tybet, świadczyły o pożądanych cechach alpinisty, czyli o umiejętności oceny sytuacji, ostrożności, co przekładało się na rezygnację z brawury. Mallory odznaczał się cierpliwością, wiedział, że zdobycie wiedzy o górach, skrupulatne

11 Ibidem.

12 B. Romaniszyn, Ideologia apinistyczna Mallory'ego (Wyprawy na Mount Everest), ,Wierchy" 3,1925 , s. 89-117. 
zbieranie informacji, przygotuje jego samego, a także zapewni maksimum bezpieczeństwa towarzyszącym mu osobom. Obcowanie z grozą gór, stawianie czoła trudnościom, jak dodaje Romaniszyn, kształtowały niezłomną wolę tego wspinacza, dzięki czemu mimo tragicznego finału drugiej wyprawy, kiedy podczas trzeciego podejścia prowadzonego przez Mallory’ego zginęło siedmiu szerpów, podjął decyzję o udziale w trzeciej ekspedycji na Mount Everest, w czasie której sam stracił życie.

Romaniszyn w opisie przebiegu ostatniego ataku Mallory’ego na „Matkę-Gór" w 1922 r. uwypuklił nie tylko wytrwałość, niezłomność wspinaczy angielskich, lecz także ich bohaterstwo, kiedy po uwolnieniu się spod lawiny ,rzucili się do ratowania kulisów”13 i ,przywrócili do życia siedmiu z nich"14. Heroizm Mallory'ego i jego dwóch towarzyszy ukazał w kategoriach walki z groźną przyrodą, symbolizowaną przez Mount Everest, górę, która rzuciła przeciwko człowiekowi cały arsenał broni w postaci „,straszliwych burz śnieżnych”, „morderczego wichru”, „podbiegunowych mrozów”, „potwornych lawin”. Troskę o drugiego człowieka Mallory przejawiał, dbając o jego bezpieczeństwo fizyczne, np. podejmując decyzję o odwrocie w momencie pojawienia się przeszkód, które realnie zagrażały życiu uczestników wyprawy. Istotniejsza jednak była dla niego, zdaniem Romaniszyna, sfera duchowa, kształtowana i wzbogacana poprzez obcowanie z majestatem gór. Wrażliwość na piękno gór, umiejętność dostrzegania i doceniania wartości, jakie płyną z wędrówki na szczyt, ujęto w artykule z „Wierchów” w kategoriach religijnych, bliskich mistycyzmowi. Romaniszyn wyprawy Mallory'ego na Mount Everest porównywał do pielgrzymek; podobnie jak człowiek wędrujący do sanktuarium, tak i alpinista prawdziwą radość odczuwa w trakcie samej wędrówki, a nawet podczas snucia jej wizji, w trakcie przygotowań. Zdobycie szczytu to ukoronowanie owej pielgrzymki, ale nie ten moment dla Mallory’ego był najważniejszy, bo oznaczał odkrycie tajemnicy. Tymczasem obcowanie z groźną, obcą, wzbudzającą podziw, ekstazę przyrodą wyzwalało w człowieku siły, których do końca sam sobie nie uświadamiał. W czytaniu filozofii, odkrywaniu mądrości gór i poznawaniu własnej duszy Mallory'emu pomagały zabierane na wyprawy lektury. Romaniszyn, wymieniając tytuły (antologia The Spirit of Men przygotowana przez Roberta Bridgesa, Król Lear i Hamlet Szekspira), podkreślał, że idee płynące z tych tekstów, czytanych wieczorami na głos, współgrały z rozważaniami filozoficznymi kształtującymi postawę etyczną ${ }^{15}$. Szacunek dla człowieka, przezwyciężającego swoje słabości dzięki sile ducha, u Mallory’ego łączył się z podziwem dla bogactwa otaczającej go przyrody, natury, której ludzkość jest cząstką. Owej jedności doświadczał alpinista w kontakcie z nieskażoną ludzką ręką przyrodą, zarówno będąc wysoko na zboczach szczytów himalajskich, jak i w świętych dla Tybetańczyków dolinach zadziwiających bogactwem flory i fauny. Nie bez powodu ze sprawoz-

13 Ibidem, s. 99.

14 Ibidem.

15 Ibidem, s. 109-110. 
dań Mallory'ego Romaniszyn wydobył fragmenty świadczące o odczuwaniu wzniosłości, w duchu Nietzschego, na widok krajobrazu himalajskiego roztaczającego się wokół alpinistów. Dla autora artykułu, propagatora haseł utworzenia w Tatrach parku narodowego, aktywnego działacza na rzecz ochrony przyrody, słowa jednego z najsłynniejszych dwudziestowiecznych wspinaczy o radości, której źródła tkwiły w kontakcie z górami, były szczególnie ważne, ponieważ legitymizowały jego osobiste poczynania i utwierdzały w słuszności głoszonych idei. Ochrona przestrzeni górskiej, rezygnacja, jak pisał Mallory, z „ewangelii gór", a więc z eksploracji obszarów wysokogórskich nastawionej na bicie rekordów i na odkrywanie wszystkich bez wyjątku tajemnic gór, winny lec u podstaw współczesnego alpinizmu. Alpinizm Mallory’ego zasadzał się, zdaniem Romaniszyna, na założeniach etycznych i estetycznych. Poznawanie gór w kategoriach sztuki zaspokajało najgłębsze potrzeby emocjonalne człowieka. Doświadczając w górach skrajnych uczuć — od grozy, strachu, po zadowolenie, radość — człowiek doznawał wzniosłości, spotęgowanej świadomością przekraczania słabości fizycznych i psychicznych. Przebywanie, zwłaszcza w wysokich partiach gór, balansowanie na granicy życia i śmierci, testowanie własnych możliwości, znoszenie kolejnych barier w wymiarze fizjologicznym, fizycznym, emocjonalnym służyło kształtowaniu charakteru, ducha, ale nie w celu uzyskania lepszego wyniku na skali osiągnięć ludzkich, lecz w celu oddania hołdu górom.

Romaniszyn, czyniąc Mallory’ego głównym bohaterem swojego tekstu, połączył rozważania angielskiego wspinacza na temat istoty poznawania gór z coraz głośniejszymi na początku XX w. ideami głoszonymi przez niemieckich $i$ austriackich alpinistów. Trzy lata po opublikowaniu artykułu Romaniszyna zamieszczono w „Wierchach” przetłumaczony i skomentowany tekst Eugena Guido Lammera, austriackiego wspinacza i publicysty ${ }^{16}$. Przesłanie artykułu korespondowało z propagowanymi ideami alpinizmu Mallory’ego, zwłaszcza w części poświęconej konieczności ochrony przyrody, w tym krajobrazu wysokogórskiego. Lammer odwoływał się do argumentacji natury religijnej, kiedy porównywał góry do świątyni, a człowieka do gościa, który winien oddawać cześć bóstwu w jego domu. Realnymi znakami szacunku i jednocześnie przejawami przemyślanych dalekowzrocznych planów obejmujących eksplorację gór miała być likwidacja wszelkich śladów obecności człowieka w najwyższych partiach. Lammer postulował usunięcie pozostawionych przez wspinaczy haków, lin, łańcuchów, wszelkich wskazówek ułatwiających dojście do konkretnego punktu czy zdobycie szczytu. Nie widział również miejsca w przestrzeni wysokogórskiej dla schronisk, gospód, szop, wiat, drogowskazów. Pragnął, wzorem Mallory’ego, aby człowiek obcował tylko z niczym nieskażoną przyrodą, dzięki czemu doznawałby kontaktu z praźródłem bytu. Autentyczny alpinista jako przeciwień-

16 Tekst Guido Lammera pt. Unbedingter Naturschutz des alpinen Oedlandes został przetłumaczony we fragmentach przez Józefę Abramowicz i opatrzony komentarzem Jana Gwalberta Pawlikowskiego. Zob. J.G.P [właśc. J.G. Pawlikowski], Z ideologii wspótczesnego alpinizmu, „Wierchy” 6, 1928, s. 155-164. 
stwo turysty-pożeracza szczytów doznawał w górach uczuć pozwalających na przekraczanie wewnętrznych granic, zerwanie gorsetu, jaki nałożyła na niego współczesna kultura. Rezygnacja z dążenia do zysku, zapewnienia sobie wygody i zarzucenie rywalizacji za wszelką cenę to powrót do idei odkrywania ,ducha gór", a w obliczu toczących się dyskusji na temat przyszłości alpinizmu hasła te były w kontrze do alpinizmu sportowego, spychającego na margines wartości estetyczno-etyczne. Podobnie jak w wypadku eksploracji Himalajów przez Mallory’ego, tak i alpiniści w wizji Lammera winni poszukiwać w górach samych siebie i koncentrować się na wewnętrznych przeżyciach, ćwiczyć instynkt górski pozwalający na indywidualne wytyczanie ścieżek do szczytów. W entuzjastycznym tonie, propagującym idee malloryzmu wypowiadał się przywoływany już Marian Sokołowski, który był przekonany o tym, że likwidacja wszelkich znaków obecności w eksploracji szczytów pozwoli kolejnym pokoleniom wspinaczy na dogłębne odczuwanie kontaktu z wyjątkową przestrzenią, jaką są góry, oraz doznawanie poczucia satysfakcji z samodzielnego odkrywania przejść, podążania własnymi drogami ${ }^{17}$.

O stanach emocjonalnych najwyższej miary, znaczeniowo sytuujących się w zakresie pojęcia szczęścia, pisał na łamach „Wierchów” w 1930 r. Mariusz Zaruski. Założyciel Tatrzańskiego Ochotniczego Pogotowia Ratunkowego definiował alpinizm następująco:

Istotą alpinizmu jest poczucie szczęścia, wynikające z samego faktu pobytu w wysokich górach, uwarunkowane jednak tym, żeby człowiek czuł się uzdolniony do poruszania się w nich z zupełną swobodą i pewnością ${ }^{18}$.

Z definicji wypływała charakterystyka współczesnego alpinisty. Odznaczał się on: siłą fizyczną, zdrowiem, zręcznością, znajomością technik wspinaczkowych oraz topografii gór. Oprócz cech odnoszących się do fizyczności Zaruski akcentował przymioty charakteru, a więc pierwiastek etyczny i konieczność odczuwania szczególnej więzi z górami, szanowania tej przestrzeni, obdarzania jej miłością. Do opisu idei alpinizmu włączył zatem argumentację natury psychologicznej. Obcowanie z górami w ich najwyższych partiach było równoznaczne z poczuciem szczęścia, co łączyło w sobie aspekty wyznawcy, zdobywcy, adepta sztuki. Dla alpinisty źródłem szczęścia może być bowiem kontakt z transcendencją; przekraczanie granic świata realnego; wzbogacanie wiedzy, np. na temat budowy geologicznej gór; pokonywanie słabości, ograniczeń fizycznych czy emocjonalnych; doświadczanie poczucia obcowania z obiektami, zjawiskami traktowanymi jako piękne, oryginalne, wyjątkowe. Zaruski nie kwestionował poszukiwań nowych, nawet ekstremalnych dróg wspinaczkowych, improwizowania przejść, pod warunkiem jednak, że istota tych przedsięwzięć nie tkwiła

17 Zob. M. Czyż, Dlaczego chodzimy po górach? Czyli o motywach uprawiania sportów wysokogórskich w świetle publikacji Jana Alfreda Szczepańskiego, „,Folia Turistica” 2010, nr 23, s. 247.

18 M. Zaruski, O istocie alpinizmu, „Wierchy” 8, 1930, s. 56.

Góry, Literatura, Kultura 11, 2018

(C) for this edition by CNS 
tylko w kwestiach technicznych. Treść alpinizmu zasadzała się, jego zdaniem, na wewnętrznym przeżyciu, indywidualnym odkrywaniu podczas wspinaczki tajników własnej duszy ${ }^{19}$.

W latach międzywojennych, kiedy zdobyto praktycznie wszystkie szczyty Alp i rozpoczęto na szeroką skalę eksplorację gór na innych kontynentach, uwagę środowiska wspinaczy coraz częściej przykuwali ci, którzy podejmowali się osiągnięcia celów „na granicy ludzkich możliwości”. Korzystając z techniki hakowej między innymi Włosi (np. Emilio Comici, Gino Esposito) i Niemcy (Gustaw Lettenbauer, Franz i Toni Schmidowie, Andreas Heckmair) wytyczali nowe drogi o wysokim stopniu trudności na Civette, Eiger, Matterhorn. Alpiniści, dla których najistotniejsze było poszukiwanie nowych tras wspinaczkowych, dotarcie do celu w jak najkrótszym czasie, zyskiwali status gwiazd alpinizmu sportowego. Ich wyczyny w prasie specjalistycznej opisywano najczęściej albo w sposób krytyczny, uznając je za sprzeniewierzenie się ideologii wspinaczki klasycznej, albo w tonie entuzjastycznym, upatrując $\mathrm{w}$ tego typu podejściu do zdobywania szczytów pożądanych dróg rozwoju alpinizmu ${ }^{20}$.

W Polsce w latach dwudziestych XX w. do głosu doszło młode pokolenie taterników, które zaczęło poszukiwać nowych wyzwań. Zbigniew Korosadowicz, Wiesław Stanisławski, Jan Staszel i Jan Alfred Szczepański (ograniczono się do kilku nazwisk) to entuzjaści wspinaczki sportowej. Szczepański publikował w „Wierchach”, „Turyście w Polsce”, a przede wszystkim w „Taterniku”, artykuły popularyzujące zawodowy alpinizm i taternictwo. Za swoistego rodzaju manifest owej ideologii można uznać tekst $Z$ rozważań nad istota taternictwa z $1925 \mathrm{r}$. z numeru 1-2, "Taternika” ${ }^{21}$. Początek nowego trendu w taternictwie, według publicysty, to rok 1924, kiedy tworzą się zręby zimowej eksploracji Tatr. Szczepański jako przedstawiciel buntującego się młodego pokolenia odrzucał zapatrywania „starych” na istotę wspinaczki, które czerpały jeszcze z dziewiętnastowiecznych idei wykładających sens obcowania człowieka z górami. W dosyć ostrych słowach krytykował Jana Gwalberta Pawlikowskiego, pisząc: „Taternictwo epoki Pawlikowskiego było dorywczym, wakacyjnym błądzeniem po górach"22. Nie zgadzał się, aby taternikiem nazywać każdego, jak chciał Pawlikowski, kontemplującego osobiście piękno gór i „chłonącego dobra duchowe, które Tatry dają"23. Taternik, zdaniem Szczepańskiego, uprawiał wspinaczkę systematycznie, fachowo przez cały rok, a nie przypadkowo. Autor $Z$ rozważań nad istota taternictwa nie oszczędzał także Mariana Sokołowskiego, którego wizja rozwoju eksploracji gór ${ }^{24}$ skłoniła do polemiki także wspomnianego już Pawlikowskiego. Szczepański propozycje Soko-

19 Por. Z. Krawczyk, Człowiek i natura. Filozoficzne założenia ideologii taterniczej i marynistycznej Mariusza Zaruskiego, „Studia Filozoficzne” 1968, nr 2, s. 61-83.

20 Zob. E. Roszkowska, Alpinizm europejski..., s. 256-274.

21 J.A. Szczepański, Z rozważań nad istotą taternictwa, ,Taternik” 1925, nr 1-2, s. 6-11. Zob. również A. Burghardt, Jan Alfred Szczepański jako ideolog gór, „,Wierchy” 58, 1992, s. 25-40.

22 J.A. Szczepański: Z rozważań nad istota..., s. 10-11.

23 J.G. Pawlikowski, O ideologię i przyszłość taternictwa, ,Wierchy” 3, 1925, s. 273.

24 M. Sokołowski, op. cit. 
łowskiego co do przyszłości taternictwa nazywał „wstecznymi i mdłymi zasadami"25. Podważał tezę swojego adwersarza o traktowaniu taternictwa jako ,symbolu pełnego życia" 26 . Dla Szczepańskiego taternictwo nie było figurą retoryczną, ale „sensem życia”, nie miało nic wspólnego z romantycznymi, rycerskimi wyprawami. Stanowiło natomiast integralną część codziennego życia osoby wspinającej się na szczyty, nawet wówczas, kiedy ,przez długie miesiące żyła [ta osoba - KT] w dużym mieście, z dala od kościoła [...] kultu”27.

Szczepański nie zgadzał się z zaproponowaną przez Sokołowskiego definicją taternictwa jako sportu, krytykując przede wszystkim wpisywanie w eksplorację gór motywów współzawodnictwa i rywalizacji, które, zdaniem autora $Z$ rozważań nad istota taternictwa, stały w sprzeczności z indywidualizmem cechującym wspinaczkę wysokogórską. W 1931 r. w tekście pod tytułem Syntezy z perspektywy dziesięciolecia Szczepański pisał o istocie triumfów taternickich będącej, jego zdaniem, efektem połączenia elementów: uczuciowego - owej namiętności - z elementem rozumowym, pozwalającym na realną ocenę możliwości i wybór najskuteczniejszego w osiągnięciu celu rozwiązania ${ }^{28}$. Szczepański w teoretycznych rozważaniach na temat ideologii taternictwa, mimo wyartykułowanej w 1925 r. postawy, próbował pogodzić poglądy „starych”, akcentujące w obcowaniu z przestrzenią górską doznania natury estetyczno-poznawczej, ze stanowiskiem „młodych”, uwypuklającym pierwiastek rywalizacji, a poznawczy tylko, jeżeli cechował się wysokim stopniem trudności lub oryginalności. W relacjach z wypraw wysokogórskich, w których Szczepański brał udział, dominowały natomiast poglądy przyznające prymat ideom sportowym przyświecającym współczesnym mu eksploratorom gór. W 1935 r., kiedy taternik uczestniczył w ekspedycji w Wysoki Kaukaz, pisał jednak:

Wyprawa powiedziała sobie krótko: będziemy się starali działać jak najwięcej, wyruszymy w środkową, i we wschodnią, i w zachodnią część gór; tam, gdzie dotrzemy piersi, będziemy odkrywcami; tam, gdzie odkrywcy zjawili się przed nami, będziemy sportowcami na dziewiczych ścianach i graniach; pola do działania nie zabraknie ${ }^{29}$.

W zacytowanej wypowiedzi brzmią tony charakterystyczne dla idei alpinizmu sportowego, pojęcia, którego jeszcze pięć lat wcześniej nie chciał używać $\mathrm{W}$ odniesieniu do typu uprawianej przez siebie wspinaczki. W dalszej partii tekstu autor eksponował momenty dowodzące przywiązywania dużej wagi do osiąganych przez członków wyprawy rezultatów i pozostawiania znaków informujących innych o ich obecności w tej przestrzeni, znaków świadczących jednocześnie o poskromieniu żywiołów natury. Odkrywając nieznaną turnię,

25 J.A. Szczepański, op. cit., s. 7.

${ }^{26}$ Ibidem, s. 8.

27 Ibidem, s. 10.

28 J.A. Szczepański, Syntezy z perspektywy dziesięciolecia, „Taternik” 15, 1931, nr 2, s. 32-36.

29 J.A. Szczepański, Polska wyprawa wysokogórska w Atlas, ,Wierchy” 13, 1935, s. 16. 
ustawiali kopczyk kamieni. Rejestrowali w skupieniu dane o wejściu, sporządzali drobiazgową dokumentację fotograficzną i uzupełniali istniejące nazwy nowymi składnikami wskazującymi na nich jako odkrywców. Kiedy dotarli na upatrzony szczyt, Szczepański zapisał: „Kopczyk szczytowy i puszka z tekstem zdobywczym powiedzą o nas następcom" ${ }^{30}$. Ingerencja w naturalne ukształtowanie rzeźby terenu przez celowe pozostawianie w ścianach haków, układanie pryzm kamieni stały w sprzeczności z postulatami Mallory’ego, Lammera, Pawlikowskiego, Jana Kazimierza Dorawskiego ${ }^{31}$, traktujących człowieka w górach jako element obcy w tej przestrzeni, wpuszczony w jej granice tylko na pewnych zasadach. Forma sprawozdania w partiach poświęconych wspinaczce przypominała opisy dróg wejścia charakterystyczne dla alpinistów sportowych. Szczepański nie zarzucał jednak czytelnika specjalistyczną terminologią, drobiazgowymi wskazówkami, gdyż założony adresat tych tekstów był masowy, o czym też informował w zakończeniu artykułu:

Wyniki propagandowe wyprawy streściły się za granicą w licznych artykułach prasy marokańskiej i sprawozdaniach alpinistycznych, a w Polsce w około 150 artykułach wysyłanych przez uczestników wyprawy do wszystkich niemal ważniejszych dzienników krajowych ${ }^{32}$.

Wyprawa w Atlas, podobnie jak inne organizowane poza Tatry, świadczyły przede wszystkim o zmianach w postrzeganiu gór jako przestrzeni ograniczającej człowieka w jego zamierzeniach eksploracyjnych. Rozwój taternictwa zimowego, sukcesy odkrywcze i wspinaczkowe w Alpach, Andach, Atlasie Wielkim, Kaukazie, na Spitsbergenie ${ }^{33}$ utwierdziły polskich wspinaczy w przekonaniu o możliwości pokonywania różnego typu przeszkód: od tych wydawałoby się prozaicznych, czyli zdobycia funduszy na wyprawę, następnie zgromadzenia potrzebnej dokumentacji, aż po przełamywanie barier kulturowych, emocjonalnych. $\mathrm{W}$ dwudziestoleciu międzywojennym rodzime góry dla ambitnych, młodych, sprawnych fizycznie taterników okazały się za niskie, za mało skomplikowane, zbyt znane. Szczepański pisał o tym tak:

Może nawet nie przesilenie się sportu taternickiego, może nawet nie owo wciąż zapowiadane a więc tak mało widoczne „wyczerpanie się problemów tatrzańskich" skierowało ekspansję taterników polskich w Alpy i poza Europę. W o wiele większym stopniu przyczyną było pojawienie się w Tatrach pokolenia, którego możliwości odkrywcze i sportowe po raz pierwszy w sposób wyraźnie przewyższały wszelkie te zadania,

30 Ibidem, s. 30 .

31 Zob. J.K. Dorawski, O sztucznych ułatwieniach wspinaczki, „Taternik” 1933, nr 2, s. 27-28.

32 J.A. Szczepański, Polska wyprawa..., s. 33.

33 Sprawozdania z tych wypraw w dwudziestoleciu regularnie drukował m.in. „Taternik”. Zob. również J. Wojsznis, Polacy na szczytach świata: wybór tekstów uczestników siedmiu wypraw alpinistycznych w latach 1933-1939 (Andy, Spitsbergen, Atlas, Kaukaz, Andy, Ruwenzori, Himalaje), Warszawa 1964. 
jakie mógł postawić przed nimi teren wysokogórski tatrzański. Z chwilą zdobycia zachodniej ściany Łomnicy oraz północnej ściany Małego Kiezmarskiego Szczytu latem i zimą, pokolenie, które tego dokonało nie miało co w Tatrach robić, chociażby je jeszcze dziesiątki podobnych problemów oczekiwało. Każdy taki następny problem nie byłby już postępem, drogą naprzód i wzwyż. Pozostał więc jako główne zadanie dla młodych i wyrabiających się, ale przestał być nim dla indywidualności czołowych przerastających tatrzańskie granice wysilania się do ostatka. Pokolenie to powiedziało sobie zatem, że przyszłość taternictwa leży poza Tatrami ${ }^{34}$.

Duch sportowy cechujący wielu młodych taterników poszukujących nowych wyzwań, wytyczających cele, których osiągnięcie zapewniłoby im miejsce w annałach alpinizmu, nie zepchnął całkowicie w niebyt idei przyświecających ich poprzednikom. Szczepański, głoszący w 1925 r. hasła sprowadzenia taternictwa do poziomu życia codziennego, kierowania się rozumem a nie sercem, sytuował się w szeregu zwolenników postulujących „zrzucenie z ramion płaszcza Konrada”, $\mathrm{i}$ to na różnych płaszczyznach aktywności ludzkiej. Jego późniejsze relacje z wypraw wysokogórskich dowodzą jednak, że nie potrafił całkowicie wyeliminować ze swojego słownika i wypowiedzi słów, zwrotów, tonu o proweniencji romantycznej. Przebywanie w egzotycznej scenerii, której najważniejszym rekwizytem były nieznane wcześniej góry, wywoływało uczucia będące, jak sam przyznawał, „żelaznym kapitałem woli”, wyzwalające dodatkowe pokłady energii wewnętrznej. Używając określeń superlatywnych, pisał o „fantastycznych, porywających, jedynych w swoim rodzaju dniach". Przyrodzie nadawał cechy ludzkie, a zatem „wiatr szalał”, „kurniawa się wściekała”, „gwiazdy zapalały śnieg”. Nieobce były mu także, podawane wcześniej w wątpliwość, z ducha nietzscheańskie tezy o heroicznym pokonywaniu własnych słabości, wystawianiu na próbę sił fizycznych, przesuwaniu granic wewnętrznych możliwości, pragnień. Chęć odkrywania miejsc dotąd nieznanych, zdobywanie o nich wiedzy, czyli wypełnianie białych plam alpinizmu, to motywacja korzeniami tkwiąca przecież jeszcze w alpinizmie odkrywczym XVIII i XIX w.

Przestrzeń górska ukazana jako miejsce niepowtarzalne, obcowanie z nieskażoną przyrodą, gwarantujące wyjątkowe doświadczenia i pozwalające poznać własne możliwości to motywy przewijające się często w artykułach o tematyce górskiej drukowanych na łamach czasopism podejmujących szeroko rozumianą problematykę krajoznawczo-turystyczną. Sposób pisania o eksploracji gór w „Ziemi” czy w „Turyście w Polsce” podporządkowano celom przyświecającym wydawaniu tych periodyków, a w konsekwencji możliwościom recepcyjnym założonych odbiorców, spośród których wielu w ogóle nie miało okazji brać udziału w jakiejkolwiek wyprawie, wycieczce górskiej. W „Ziemi” publikowano wypowiedzi dotyczące przede wszystkim kwestii fizjograficznych danego obszaru,

34 Ibidem, s. 16. 
form i rodzaju działalności człowieka wpływających na środowisko naturalne, ukształtowanie krajobrazu. Dlatego też na łamach tego warszawskiego periodyku najwięcej miejsca poświęcano ochronie środowiska górskiego i lokalnego krajobrazu, wykorzystując szablony, które równie dobrze funkcjonowałyby w tekście o innych zakątkach Polski. Podkreślano zatem walory Tatr, Pienin, Beskidów, przekonując czytelników, że obcowanie z nieskażoną przyrodą przynosiło nieocenione korzyści wszystkim, bez względu na wiek, zawód, motywację, jaka przyświecała wędrówkom po górach. Jednoznacznie popierano inicjatywę powołania parku narodowego w Tatrach i krytykowano pomysły zmierzające do przekształcenia naturalnego krajobrazu górskiego, do czego doprowadziłaby np. budowa kolejki linowej na Kasprowy Wierch. Ton, w jakim wypowiadał się chociażby Bolesław Hryniewiecki, atakując zwolenników rozbudowy infrastruktury turystycznej $\mathrm{w}$ wysokich partiach gór, sytuował artykuły publikowane na łamach „Ziemi” w grupie tekstów propagujących idee taternictwa w rozumieniu klasycznym ${ }^{35}$.

Wpisanie założeń regionalizmu w ramy oficjalnej polityki państwowej skutkowało między innymi podejmowaniem pod patronatem państwa inicjatyw mających na celu rozwój turystyki o charakterze masowym. Publicyści związani z organizacjami i stowarzyszeniami o charakterze turystyczno-krajoznawczym, pisząc o turystyce jako ruchu społecznym wykraczającym poza dosyć elitarny do tej pory krąg osób pasjonujących się wyprawami górskimi ${ }^{36}$, kładli nacisk na aspekty wychowawcze i kształcące. Walery Goetel w 2 . numerze „Turysty w Polsce” wyróżnił dwa nurty w turystyce i wskazał zależności między turystyką a krajoznawstwem. Goetel zaakceptował popularyzowane coraz częściej formy turystyki biernej, kiedy podróżujący korzystali ze środków komunikacji zapewniających im wygodę i komfort przemieszczania się $\mathrm{z}$ jednego miejsca $\mathrm{w}$ drugie. Pisał o tym sposobie poznawania przestrzeni bez entuzjazmu, widząc $\mathrm{w}$ turystyce biernej przede wszystkim element gospodarki, dodatkowe źródło dochodu państwa. Inaczej postrzegał turystykę czynną, w charakterystyce której akcentował zalety pieszych wędrówek, bezinteresownego obcowania z przyrodą:

częste wyrwanie się z kieratu codziennego miejskiego życia na swobodę pogłębia w turystach czynnych znajomość i miłość Ojczyzny utrzymuje w nich świeżość i młodzieńczość ducha i usposobienia ${ }^{37}$.

Przypisanie wyznaczników charakterystyki tożsamości grupowej (narodowej) eksploracji przestrzeni fizycznej, o której w czasopismach specjalistycznych $\mathrm{z}$ dwudziestolecia międzywojennego $\mathrm{w}$ odniesieniu do gór pisano przede

35 B. Hryniewiecki, Walka o Park Narodowy w Tatrach, „Ziemia” 1934, nr 1-2, s. 12-16; idem, Szczyty, technika, kultura, „Ziemia” 1934, nr 5, s. 93-96.

36 Zob. M. Praczyk, Elitaryzm środowiska polskich taterników w dwudziestoleciu międzywojennym na przykładzie biografii Wincentego Birkenmajera, „Góry — Literatura — Kultura” 9, 2015, s. 82.

37 W. Goetel, Na drogach wspótpracy turystyki czynnej, „Turysta w Polsce” 1935, nr 2, s. 2. 
wszystkim w kategoriach indywidualnego wyczynu, zapowiadało przesunięcie w dyskusjach na temat ideologii taternictwa punktu ciężkości na elementy innego rodzaju — społeczne. Pisał o nich wcześniej, krytykowany zresztą przez środowisko taterników, przywoływany już Mariusz Zaruski. Był on nie tylko jednym z pionierów zimowych wspinaczek, lecz także propagatorem narciarstwa i wycieczek narciarskich. Organizowanie wycieczek w góry, zwłaszcza w Tatry, to temat przewodni wielu artykułów drukowanych na łamach ,Turysty w Polsce". Owo zagadnienie poruszano między innymi w kontekście wychowywania i kształcenia młodzieży. Władysław Krygowski np. szczególną wagę przywiązywał do jednej z form turystyki masowej, jaką było „obozownictwo i dalekobieżne wędrówki górskie"38. Widział w nich narzędzie pozwalające ćwiczyć charakter, samodzielność, a także umiejętność współpracy i koleżeństwa, czyli cechy pożądane u alpinisty. Włodzimierz Firsoft przekonywał czytelników o wyjątkowym wpływie taternictwa na charakter, usposobienie uprawiających go osób. Jego zdaniem wspinaczka, zwłaszcza w wysokich partiach gór, dostarczała przeżyć o „olbrzymiej skali, uczuć o silnych napięciach i niecodziennej treści”39, co nie tylko budowało hart ducha i ciała, lecz także wzbogacało osobiste doświadczenia poprzez zagłębienie się w psychikę człowieka stawianego niejednokrotnie w obliczu niebezpieczeństwa lub konieczności podejmowania szybkich, ryzykownych decyzji. Firsoft jednocześnie ubolewał nad zachowaniami burzącymi harmonię przeżywania kontaktu z górami, czego egzemplifikacją były rekordomania i rezygnacja z pielęgnowania specyficznej więzi łączącej osoby wspinające się wspólnie na szczyty. Źródeł owych negatywnych zjawisk publicysta upatrywał w ,uspołecznieniu taternictwa"40. Krytyka umasowienia turystyki górskiej korespondowała z głosami na temat konieczności wychowywania młodego pokolenia, kształcenia w nich umiejętności świadomego obcowania z przestrzenią górską, co w przyszłości będzie gwarantem czerpania z owego kontaktu ,radości i okrasy życia"41.

Lektura wybranych wypowiedzi publikowanych na łamach czasopism turystyczno-krajoznawczych o charakterze specjalistycznym oraz tych adresowanych do szerokiego grona odbiorców pozwala na wyodrębnienie dwóch szczególnie wyróżniających się nurtów w opisie eksploracji przestrzeni górskiej w wymiarze transgresji. Jeden z nich tworzyły teksty przedstawiające wspinaczkę, zwłaszcza w wysokich partiach gór, jako aktywność właściwą tylko wąskiemu kręgowi osób — „wtajemniczonym”. Autorzy tych artykułów zastanawiali się nad istotą alpinizmu, jego odmianami, zaletami oraz wadami nowych technik wspinaczkowych i sposobów penetrowania przestrzeni górskiej. Autorzy drukujący w periodykach przygotowywanych z myślą o czytelniku masowym (notabene wielu

38 W. Krygowski, Obozy wędrowne i dalekobieżne wędrówki górskie, „Turysta w Polsce” 1935, nr 5, s. 3. Zob. także F. Rapf, Wycieczki szkolne w Tatry, „Turysta w Polsce” 1935, nr 5, s. 4-5.

39 W. Firsoft, Taternictwo ksztatci charakter, „Turysta w Polsce” 1935, nr 6, s. 12.

40 Ibidem.

${ }^{41}$ K. Sosnowski, Pieniny w zimowej szacie, „Turysta w Polsce” 1935, nr 10, s. 12. 
z nich tworzyło także prasę specjalistyczną) próbowali definiować taternictwo/ alpinizm w kontekście procesów umasowienia obejmujących również turystykę w każdym z jej przejawów. Można jednak zauważyć, że bez względu na typ czasopisma i dominujące $\mathrm{w}$ artykułach motywy w większości wypowiedzi pojawiały się fragmenty dotyczące niwelowania przeszkód, znoszenia granic różnego typu, np. terytorialnych (wyprawy poza Tatry), fizjologiczno-emocjonalnych (alpinizm akrobatyczny), duchowych. Te ostatnie najtrudniej uchwycić, gdyż stanowiły i stanowią do dziś obszar indywidualnych doznań każdego z alpinistów w kontakcie z przestrzenią górską. 